\title{
Role of dexmedetomidine in myocardial protection during beating coronary artery bypass grafting.
}

\author{
Sarvaia A. ${ }^{1}$, Pujara J. ${ }^{2}$, Sarvaiya V. ${ }^{3}$, Pandya H. ${ }^{4}$, Trivedi V. ${ }^{5}$, Ninama S.K. ${ }^{6}$, Acharya H. ${ }^{7}$ \\ ${ }^{1}$ Dr. Alpesh Sarvaia, Senior Resident, Department of Cardiac Anesthesia, ${ }^{2}$ Dr. Jigisha Pujara, Associate Professor, \\ Department of Cardiac Anesthesia, ${ }^{3}$ Dr. Varsha Sarvaiya, Professor, Department of Cardiac Anesthesia, ${ }^{4}$ Ms. Himani \\ Pandya, Research Associate Department of Research, ${ }^{5}$ Dr. Visharad Trivedi, Assistant Professor, Department of Cardiac \\ Anesthesia, ${ }^{6}$ Dr. Sunil Kumar Ninama, Assistant Professor, Department of Cardiac Anesthesia, ${ }^{7}$ Mr. Himanshu Acharya, \\ Research Fellow, Department of Research, all authors are affiliated with U.N. Mehta Institute of Cardiology and \\ Research Centre, B. J. Medical College, Ahmedabad, Gujarat. India.
}

Address for Correspondence: Dr. Jigisha C. Pujara, Associate Professor, Department of Cardiac Anesthesia. Email: jigishajayesh@yahoo.com

\begin{abstract}
Background: On-pump CABG is associated with a high risk of myocardial injuries and other complications that result into myocardial ischemia and arrhythmias. OPCAB surgery may reduce, although not entirely eliminate, these myocardial injuries. This prospective study was designed to determine whether the intraoperative use of Dexmedetomidine could reduce the incidence of myocardial injuries after off pump CABG. Methods: A total of 100 patients who underwent off-pump coronary artery bypass surgery were included and randomly divided into Dexmedetomidine-treated and Control groups (groups B and A, respectively) 50 patients in each groups. Following the first vascular anastomosis grafting, the patients in group B received a loading dose of $0.5 \mu \mathrm{g} / \mathrm{kg} / 10 \mathrm{~min}$ of Dexmedetomidine via central venous catheter followed by a continuous infusion of $0.5 \mu \mathrm{g} / \mathrm{kg} / \mathrm{hr}$ of Dexmedetomidine. The infusion was discontinued at the end of surgery. In group A, $0.9 \%$ physiological saline was infused using identical methods to group B. Results: The primary outcomes measured included serum levels of cardiac biomarkers like CPKMB \& Trop I. Secondary outcomes included hemodynamic stability, ischemia or arrhythmia events \& post-operative ICU stay. Dexmedetomidine use significantly reduced postoperative CPK-MB $(26.38 \pm 7.11 \mathrm{v} / \mathrm{s} 30.48 \pm 9.84, \mathrm{P}=0.019)$ \& Trop I $(0.678 \pm 0.742 \mathrm{v} / \mathrm{s} 1.011 \pm 0.67, \mathrm{P}=0.021)$ at $24 \& 48$ hours respectively. Intraoperative dexmedetomidine therapy also reduced the risk of overall complications. Conclusion: Intra operative administration of low-dose dexmedetomidine reduces myocardial damage during off-pump coronary artery bypass grafting surgery as indicated by significantly decreased level of cardiac biochemical markers, CK-MB and cTnI post-operatively.
\end{abstract}

Keywords: Myocardial, Ischemia, Arrhythmias.

\section{Introduction}

Revascularization by Coronary artery bypass grafting $(\mathrm{CABG})$ is an effective method of treating coronary artery blockage. Conventionally $\mathrm{CABG}$ is performed under cardiac arrest with cardiopulmonary bypass (CPB), which has the potential to result in myocardial injuries, such as increased levels of cardiac biomarkers like troponin I (cTnI) and creatine kinase-MB (CK-MB) [1]. cTnI and CK-MB levels may therefore be indicative

Manuscript received: $14^{\text {th }}$ January 2017

Reviewed: $20^{\text {th }}$ January 2017

Author Corrected: $28^{\text {th }}$ January 2017

Accepted for Publication: $08^{\text {th }}$ February 2017 of the result of the surgery induced myocardial injuries.

OPCAB surgery may reduce post-surgical myocardial injuries $[2,3]$. However, the OPCAB technique is more challenging with regard to hemodynamic management, particularly during left circumflex coronary artery or posterior descending artery anastomosis [4]. Eliminating or reducing these myocardial injuries are likely to improve the prognosis in patients who have undergone cardiac surgery [2]. Therefore, various 
measures have been applied to reduce the incidence of post-surgical myocardial injuries [5, 6].

A highly selective $\alpha 2$-adrenergic receptor agonist Dexmedetomidine has been revealed to reduce the incidence of cardiovascular adverse events in patients who had received on-pump coronary artery bypass grafting [7]. Dexmedetomidine can attenuate the sympathetic response to anesthesia and surgery in patients undergoing OPCAB [8] procedures and can lead to a lower incidence of myocardial injuries [8]. Myocardial injuries were assessed by observing the hemodynamic changes, myocardial enzyme levels, myocardial ischemia and arrhythmic events.

\section{Materials and Methods}

Case selection: In this prospective single center randomized study the patients were divided into two groups. One hundred patients who were undergoing OPCAB surgery between January 2015 and December 2015 were randomly divided into dexmedetomidine-treated $(n=50)$ and Control $(n=50)$ groups (groups B and A, respectively). The study was conducted with approval from the Institutional Ethics Committee. All patients signed informed consent forms before involved in the study.

Inclusion criteria: Patients diagnosed with coronary artery lesions with ASA status I and II with sinus rhythm without any signs of heart failure posted for OPCAB surgery with plasma concentration of CPK-MB \& cTnI were within the normal ranges were included in study.

Exclusion criteria: Patients who were $>75$ years of age, preoperative history of arrhythmias, an ejection fraction of $<40 \%$ or bradycardia (Heart rate $<50$ beats/min), were excluded from the study. In addition, exclusion criteria comprised a preoperative systolic pressure $<90$ $\mathrm{mmHg}$, obesity, emergency surgery, drug dependence and a history of psychiatry and cerebrovascular diseases.

Surgical methods and medication: Following entry into the operating theatre the patients underwent radial artery cannulation under local anesthesia and the invasive arterial pressure was monitored. Anesthesia was induced in all patients by the administration of 0.1 $\mathrm{mg} / \mathrm{kg}$ Medazolam $5 \mu \mathrm{g} / \mathrm{kg}$ fentanyl and $0.1 \mathrm{mg} / \mathrm{kg}$ vecuronium bromide. After $3 \mathrm{~min}$, patients underwent oral endotracheal intubation. Intraoperative, all patients were administered $1 \mu \mathrm{g} \quad / \mathrm{kg}$ Fentanyl, $0.04 \mathrm{mg} / \mathrm{kg}$ Vecuronium and Sevoflurane for maintenance of anaesthesia. All patients underwent OPCAB through a midline sternotomy incision. Following the sawing of the sternum, the left internal thoracic arteries and simultaneously the great saphenous veins of patients were separated. Following the separation of the internal left thoracic arteries, the patients were treated with 2 $\mathrm{mg} / \mathrm{kg}$ heparin sodium. The activated clotting time (ACT) was measured $5 \mathrm{~min}$ later, and vascular anastomosis was performed a further $300 \mathrm{sec}$ later. Protamine was used for post-surgical heparin neutralization.

Following the first vascular anastomosis grafting, the patients in group B received a loading dose of 0.5 $\mu \mathrm{g} / \mathrm{kg} / 10 \mathrm{~min}$ of dexmedetomidine via central venous catheter followed by a continuous infusion of 0.5 $\mu \mathrm{g} / \mathrm{kg} / \mathrm{hr}$ of Dexmedetomidine. The infusion was discontinued at the end of surgery. The patients in group A were administered an intravenous infusion of $0.9 \%$ physiological saline, using identical methods to group B. Intraoperative haemodynamics maintained with fluid and vasopressors as per Institute protocol.

Detection indices: Hemodynamic data included heart Rate (HR), systolic arterial pressure (SBP), Diastolic arterial blood pressure (DBP), mean pulmonary artery pressure (MPAP), central venous pressure (CVP), pulmonary capillary wedge pressure (PCWP) and cardiac index (CI) were recorded before induction of anaesthesia (T0), before starting the study drug (or SP) (T1), 30min after starting the infusion (T2), and $1 \mathrm{hr}(\mathrm{T} 3), 2 \mathrm{hr}(\mathrm{T} 4), 24 \mathrm{hr}$ (T5) and 48hr(T6) after the surgery. Blood sample for biochemical markers were obtained at 5times interval; before and immediately after completion of surgery and also 12, 24 and 48 hours post operatively. At each time point, $\sim 2 \mathrm{ml}$ arterial blood was collected and centrifuged at 1,500 x g. The serum was then separated and immediately the measurement of the serum levels of cTnI and CK-MB done, via CIMA (Chemiluminescent Microparticle Immunoassay) and Immunoinhibition/IFCC method, respectively (ARCHITECT C4100 system, ABBOTT, Germany).

At $24 \mathrm{~h}$ post-surgery, a dynamic electrocardiogram was monitored and recorded for the analysis of postoperative myocardial ischemia and arrhythmia. 
Post-operative duration of ventilation and length of ICU stay were recorded accordingly.

Statistical analysis- Statistical analysis was performed using SPSS, Version 20.0 (Chicago, IL, USA). Qualitative data were expressed as proportions whereas the quantitative data was expressed as mean $\pm \mathrm{SD}$.

\section{Results}

Comparison of Baseline and Preoperative parameters- Demographic and clinical data of the patients in both of the groups are summarized in Table 1. There were no significant differences between two groups with respect to age, gender distribution, height, body weight, body surface area, medical history (smoking, incidence of diabetes \& hypertension or ejection fraction), and any preoperative medication taken by the patients, such as $\beta$-receptor inhibitors, ACE inhibitors, nitrates and calcium ion antagonists.

\section{Table-1: Demographic details}

\begin{tabular}{|c|c|c|c|}
\hline Variables & $\begin{array}{c}\text { Control Group A } \\
(\mathbf{n}=\mathbf{5 0})\end{array}$ & $\begin{array}{l}\text { Dexemedetomidine Group B } \\
(n=50)\end{array}$ & p Value \\
\hline Age (Year) & $57.54 \pm 7.58$ & $57.66 \pm 7.88$ & 0.938 \\
\hline Sex(male/female), $n$ & $35 / 15$ & $32 / 18$ & 0.6706 \\
\hline Weight (kg) & $62.22 \pm 11.16$ & $66.72 \pm 18.64$ & 0.146 \\
\hline Height $(\mathrm{cm})$ & $160.8 \pm 11.53$ & $160.72 \pm 14.34$ & 0.976 \\
\hline $\operatorname{BSA}\left(\mathrm{m}^{2}\right)$ & $1.6788 \pm 0.22$ & $1.706 \pm 0.16$ & 0.477 \\
\hline Diabetes, n (\%) & $22(44)$ & $25(50)$ & 0.6886 \\
\hline Hypertension, n (\%) & $31(62)$ & $36(72)$ & 0.3949 \\
\hline $\begin{array}{c}\text { Calcium Channel Blocker, } \mathrm{n} \\
(\%)\end{array}$ & $28(56)$ & $32(64)$ & 0.5403 \\
\hline Nitrate, n (\%) & $23(46)$ & $27(54)$ & 0.5485 \\
\hline B- Blocker, n (\%) & $29(58)$ & $27(54)$ & 0.8403 \\
\hline ACE Inhibitor, n (\%) & $24(48)$ & $27(54)$ & 0.6891 \\
\hline $\operatorname{LVEF}(\%)$ & $50.6 \pm 7.33$ & $51.1 \pm 7.58$ & 0.738 \\
\hline Smoking, n (\%) & $17(34)$ & $23(46)$ & 0.3074 \\
\hline Duration Of Surgery (Hr.) & $3.9 \pm 0.66$ & $3.86 \pm 0.53$ & 0.7404 \\
\hline No Of Vascular Graft & $3 \pm 0.88$ & $2.98 \pm 0.76$ & 0.9039 \\
\hline
\end{tabular}

Note: Values are mean \pm SD or number of patients $(\%)$. There were no significant differences between the groups ( $p>0.05)$. BSA= Body Surface Area, LVEF= Left Ventricular Ejection Fraction.

Comparison of Procedural characteristics- The durations of surgery were $3.9 \pm 0.66 \mathrm{~h}$ and $3.86 \pm 0.53 \mathrm{~h}$ in groups $\mathrm{A}$ and $\mathrm{B}$, respectively, while the numbers of vascular grafts were $3 \pm 0.88$ and $2.98 \pm 0.76$ in groups A and B, respectively. There were no significant differences between the groups for either of these characteristics $(\mathrm{P}>0.05)$. (Table 1$)$ There were no patient mortalities in either groups.

Two groups had similar baseline HR, SAP and DAP measurements (Table 2). At T2, T3 and T4 time, the heart rate in group B were significantly lower than those in control group A $(\mathrm{P}<0.05)$. No statistical differences were observed between the two groups at the other time points $(\mathrm{P}>0.05)$. Heart rate $(\mathrm{HR})$ at $\mathrm{T} 1$ to $\mathrm{T} 6$ were higher than that at $\mathrm{T} 0$ in control group A, whereas HR at T2 and T3 were significantly lower than that at T0 in Dexmedetomidine group B (Figure 1). Systolic arterial blood pressure (SAP) at T3 (Figure 2) and diastolic arterial blood pressure (DAP) at T2 and T3 were significantly lower in groups $\mathrm{B}$ than in group $\mathrm{A}(\mathrm{P}<0.05)$. 
Figure 1: Compare heart rate in control and dexmedetomidine

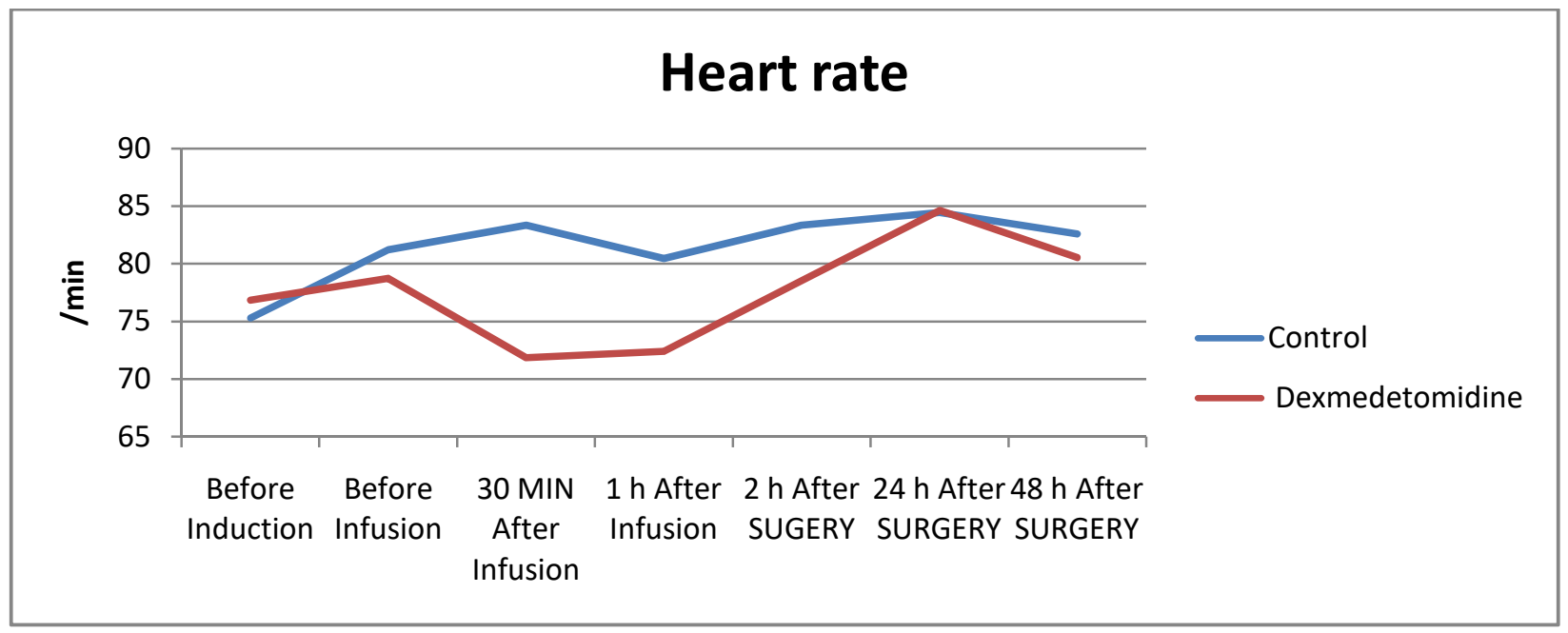

Figure-2: Compare systolic arterial pressure in control and Dexmedetomidine

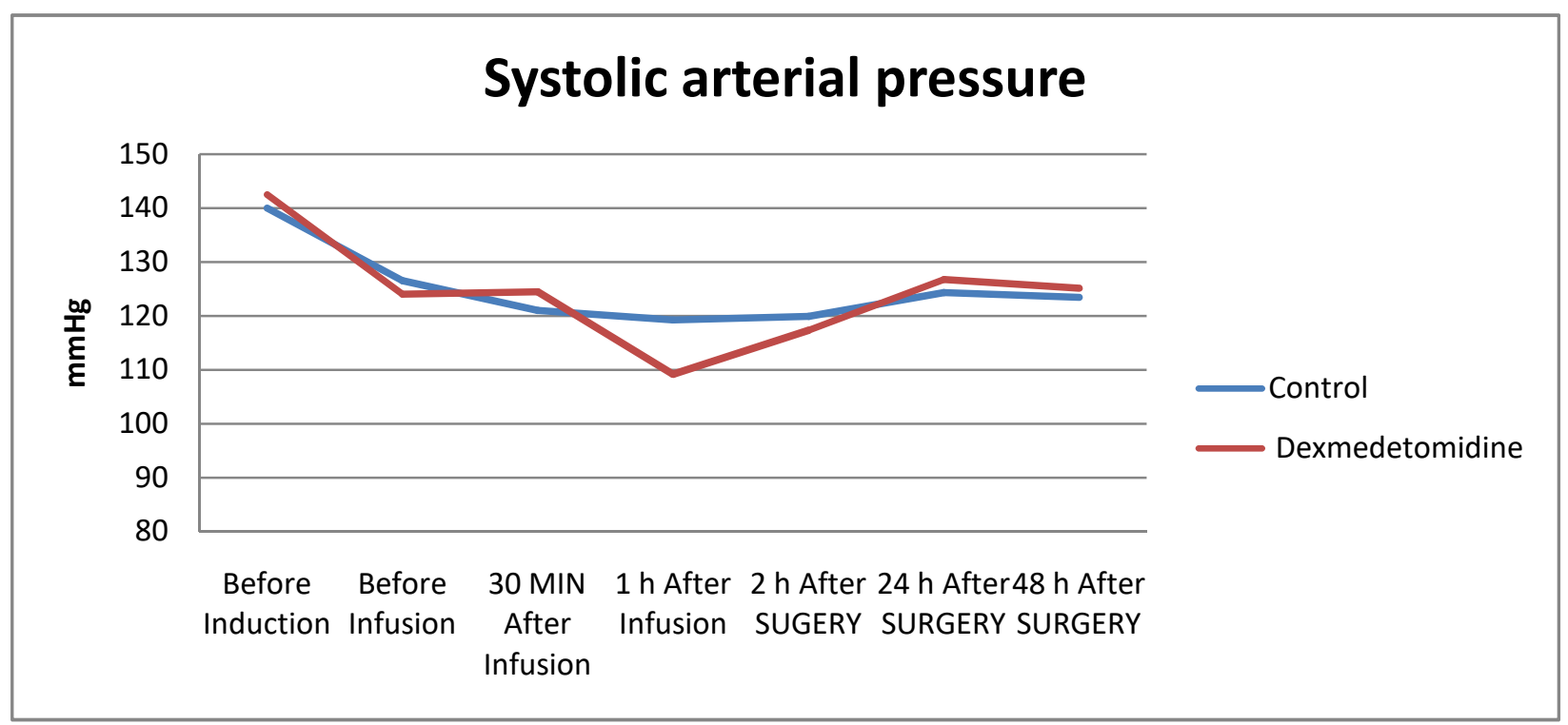

Dexmedetomidine bolus induced hypertension (increase in systolic BP $\geq 20 \mathrm{mmHg}$ ) and bradycardia (HR $<60 / \mathrm{min}$ )were observed in $8 \%$ and $6 \%$ of patients in dexmedetomidine group respectively, however they were present for a brief period only and resolved without any intervention.

Hypotension was observed in $16 \%$ of patients in dexmedetomidine group. Hemodynamic goal was to maintain mean arterial pressure $\geq 60 \mathrm{mmHg}$ and inotropes \& vasopressors were started accordingly.

Baseline CVP, MPAP \& PCWP were similar in both of the groups. CVP, MPAP and PCWP were significantly at lower side in Dexmedetomidine group B as compared to control group A.

CVP was significantly higher at all the time points when compared with baseline (T1) value in control group A, whereas it was lower in group B at T2 \&T3. In Group B, lower MPAP and PCWP values were recorded during T2 to T6 time interval than before infusion value $(\mathrm{T} 1)(\mathrm{p}<0.05)$.

In Group A, lower CI value was seen at T2 \& T3, while it was significantly increased at T5 \& T6 as compare to before infusion value than before infusion value (T1). In Group B, lower CI values was observed after starting 
dexmedetomidine loading, whereas CI increased at T4,T5,T6 level. CO significantly decreased in both the group at T2 and T3, however it was more decrease in group A as compare to group B.

Table-2: Hemodynamic Data

\begin{tabular}{|c|c|c|c|c|c|c|c|}
\hline & $\begin{array}{c}\text { Before } \\
\text { Induction } \\
(\mathrm{T0}) \\
\end{array}$ & $\begin{array}{l}\text { Before } \\
\text { Infusion (T1) }\end{array}$ & $\begin{array}{l}30 \text { min After } \\
\text { Infusion (T2) }\end{array}$ & $\begin{array}{l}1 \quad \text { hr. } \\
\text { Infusion } \\
\text { (T3) }\end{array}$ & $\begin{array}{l}2 \text { hr. After } \\
\text { SUGERY (T4) }\end{array}$ & $\begin{array}{l}24 \text { hr. After } \\
\text { SURGERY } \\
\text { (T5) } \\
\end{array}$ & $\begin{array}{l}48 \text { hr. After } \\
\text { SURGERY(T6 } \\
\text { ) }\end{array}$ \\
\hline \multicolumn{8}{|c|}{ HR (beats/min) } \\
\hline Control & $75.28 \pm 9.56$ & $81.2 \pm 9.02 \dagger$ & $83.36 \pm 7.83 * \dagger$ & $80.46 \pm 10.64 * \dagger$ & $83.34 \pm 9.64 * \dagger$ & $84.46 \pm 11.52 \dagger$ & $82.6 \pm 10.76 \dagger$ \\
\hline Dexmedetomidine & $76.86 \pm 11.26$ & $78.74 \pm 9.32$ & $71.86 \pm 9.6 \dagger$ & $72.4 \pm 8.67 \dagger$ & $78.54 \pm 8.37$ & $84.62 \pm 6.23 \dagger$ & $80.54 \pm 6.73 \dagger$ \\
\hline \multicolumn{8}{|c|}{ SAP (mmHg) } \\
\hline Control & $140 \pm 18.64$ & $\begin{array}{l}126.5 \pm 22.25 \\
\dagger\end{array}$ & $121 \pm 13.45 \dagger$ & $\begin{array}{l}119.28 \pm 13.48 * \\
\dagger\end{array}$ & $\begin{array}{l}119.88 \pm 10.97 \\
\dagger\end{array}$ & $124.32 \pm 8.51 \dagger$ & $123.44 \pm 10.85 \dagger$ \\
\hline Dexmedetomidine & $\begin{array}{c}142.46 \pm 19.8 \\
7\end{array}$ & $124 \pm 19.96 \dagger$ & $\begin{array}{l}124.46 \pm 14.62 \\
\dagger\end{array}$ & $109.2 \pm 12.06 \dagger$ & $\begin{array}{l}117.36 \pm 13.75 \\
\dagger\end{array}$ & $\begin{array}{l}126.76 \pm 11.59 \\
\dagger\end{array}$ & $125.12 \pm 8.78 \dagger$ \\
\hline \multicolumn{8}{|c|}{ DAP (mmHg) } \\
\hline Control & $75.68 \pm 7.42$ & $70.58 \pm 8.81 \dagger$ & $\begin{array}{l}70.54 \pm 7.13 * \\
\dagger\end{array}$ & $69.1 \pm 5.76 * \dagger$ & $71.22 \pm 4.94 \dagger$ & $75.32 \pm 3.37$ & $72.14 \pm 9.52 \dagger$ \\
\hline Dexmedetomidine & $75.44 \pm 8.42$ & $71.92 \pm 8.82 \dagger$ & $63.24 \pm 5.22 \dagger$ & $66.42 \pm 6.18 \dagger$ & $71.14 \pm 5.82 \dagger$ & $76.46 \pm 6.13$ & $72.26 \pm 5.65 \dagger$ \\
\hline \multicolumn{8}{|c|}{$\mathrm{CVP}(\mathrm{mmHg})$} \\
\hline Control & & $7.16 \pm 2.25$ & $8.44 \pm 1.53 * ¥$ & $8.72 \pm 1.52 * ¥$ & $9.26 \pm 1.36^{*} ¥$ & $8.78 \pm 2.19 * ¥$ & $8.5 \pm 1.88 * ¥$ \\
\hline Dexmedetomidine & & $7.3 \pm 2.69$ & $6.1 \pm 2.41 ¥$ & $6.42 \pm 2.11 ¥$ & $6.78 \pm 2.22$ & $7.18 \pm 1.62$ & $7.04 \pm 1.71$ \\
\hline \multicolumn{8}{|c|}{ MPAP (mmHg) } \\
\hline Control & & $14.92 \pm 2.23$ & $16 \pm 5.53 *$ & $14.4 \pm 2.34 *$ & $15.58 \pm 2.55^{*}$ & $15.96 \pm 2.78^{*} ¥$ & $15.04 \pm 2.52 *$ \\
\hline Dexmedetomidine & & $16.26 \pm 4.39$ & $12.28 \pm 2.07 ¥$ & $12.08 \pm 2.06 ¥$ & $12.14 \pm 2.34 ¥$ & $12.5 \pm 2.01 ¥$ & $12.58 \pm 1.62 ¥$ \\
\hline \multicolumn{8}{|c|}{ PCWP (mmHg) } \\
\hline Control & & $11.14 \pm 2.45$ & $10.82 \pm 1.75^{*}$ & $10.58 \pm 1.71^{*} ¥$ & $11.22 \pm 1.72$ & $11.16 \pm 1.7^{*}$ & $11.14 \pm 1.6^{*}$ \\
\hline Dexmedetomidine & & $11.14 \pm 2.57$ & $10.02 \pm 1.69 ¥$ & $10.02 \pm 1.69 ¥$ & $10.3 \pm 1.65 ¥$ & $9.6 \pm 1.66 ¥$ & $9.76 \pm 1.34 ¥$ \\
\hline \multicolumn{8}{|c|}{ CO (1/min) } \\
\hline Control & & $3.84 \pm 0.38$ & $3.22 \pm 0.51 * ¥$ & $3.3 \pm 0.55 * ¥$ & $3.78 \pm 0.47$ & $3.76 \pm 0.48$ & $3.88 \pm 0.39$ \\
\hline Dexmedetomidine & & $3.94 \pm 0.24$ & $3.54 \pm 0.55 ¥$ & $3.74 \pm 0.49 ¥$ & $3.9 \pm 0.42$ & $3.9 \pm 0.37$ & $3.96 \pm 0.2$ \\
\hline \multicolumn{8}{|c|}{ CI $\left(\mathrm{L} / \mathrm{min} / \mathbf{m}^{2}\right)$} \\
\hline Control & & $2.16 \pm 0.29$ & $1.92 \pm 0.32 ¥$ & $2.01 \pm 0.36 * ¥$ & $2.2 \pm 0.34$ & $2.24 \pm 0.36 ¥$ & $2.27 \pm 0.36 ¥$ \\
\hline Dexmedetomidine & & $2.23 \pm 0.25$ & $2.03 \pm 0.3 ¥$ & $2.17 \pm 0.34$ & $2.27 \pm 0.32$ & $2.27 \pm 0.32$ & $2.25 \pm 0.29$ \\
\hline
\end{tabular}

$\mathrm{P}=<0.05$ considered as a Significant $*$ between group, $\dagger$ compared with before induction value, $¥$ compared with before infusion value. Group A=Control, Group B=Dexmedetomidine

Patients in the 2 groups had similar baseline preoperative serum cTnI and CK-MB concentrations. The cTnI and CK-MB levels at T1-T5 were higher than those at T0 in both the groups. CK-MB and cTnI values peaked immediately after surgery (T1) in both the groups.

CK-MB at T3 level and cTnI at T4 level in group B (dexmedetomidine group) were significantly lower than those in group A $(\mathrm{P}<0.05)$.

No statistically significant differences were observed at the other time points $(\mathrm{P}>0.05$, Table 3 and figure 3,4$)$. 
Table-3: Concentrations of cTnI and CK-MB

\begin{tabular}{|c|c|c|c|}
\hline & $\begin{array}{c}\text { Control Group A } \\
(\mathbf{n}=\mathbf{5 0})\end{array}$ & $\begin{array}{l}\text { Dexemedetomidine Group B } \\
\qquad(\mathbf{n}=50)\end{array}$ & P value \\
\hline \multicolumn{4}{|c|}{ CK-MB } \\
\hline Before Surgery (T0) & $10.92 \pm 4.86$ & $10.9 \pm 5.55$ & 0.985 \\
\hline After Surgery (T1) & $39.44 \pm 12.40 \dagger$ & $35.86 \pm 10.90 \dagger$ & 0.128 \\
\hline $12 \mathrm{Hr}$ After Surgery (T2) & $35.14 \pm 12.29 \dagger$ & $31.98 \pm 10.15 \dagger$ & 0.164 \\
\hline $24 \mathrm{Hr}$ After Surgery(T3) & $30.48 \pm 9.84 \dagger$ & $26.38 \pm 7.11 * \dagger$ & 0.019 \\
\hline $48 \mathrm{Hr}$ After Surgery (T4) & $26.5 \pm 8.70 \dagger$ & $23.5 \pm 7.23 \dagger$ & 0.064 \\
\hline \multicolumn{4}{|c|}{ cTnI } \\
\hline Before Surgery (T0) & $0.160 \pm 0.19$ & $0.171 \pm 0.33$ & 0.8393 \\
\hline After Surgery (T1) & $3.052 \pm 1.67 \dagger$ & $2.442 \pm 1.68 \dagger$ & 0.720 \\
\hline 12 Hrs After Surgery (T2) & $2.129 \pm 1.18 \dagger$ & $2.006 \pm 1.55 \dagger$ & 0.656 \\
\hline 24 Hrs After Surgery (T3) & $1.381 \pm 0.915 \dagger$ & $1.256 \pm 1.037 \dagger$ & 0.526 \\
\hline 48 Hrs After Surgery (T4) & $1.011 \pm 0.67 \dagger$ & $0.678 \pm 0.742 * \dagger$ & 0.021 \\
\hline
\end{tabular}

CK-MB in Units/Lit, cTnI in $\mathrm{ng} / \mathrm{ml}$

$* \mathrm{P}$ Value $<0.05$ between the groups, $\dagger \mathrm{p}<0.05$ value when compared with $\mathrm{T} 0$ value

Table-4: Comparison of Post-operative outcome

\begin{tabular}{|c|c|c|c|}
\hline & $\begin{array}{c}\text { Group A Control group } \\
(\mathbf{n = 5 0 )}\end{array}$ & $\begin{array}{c}\text { Group B Dexemedetomidine } \\
(\mathbf{n = 5 0 )}\end{array}$ & P value \\
\hline Surgery duration (hours) & $3.9 \pm 0.66$ & $3.86 \pm 0.53$ & 0.7404 \\
\hline Mechanical ventilation time (hours) & $5.92 \pm 3.17$ & $5.64 \pm 2.65$ & 0.6334 \\
\hline No of Graft & $3 \pm 0.88$ & $2.98 \pm 0.76$ & 0.9039 \\
\hline ICU Stay(hours) & $78.88 \pm 15.99$ & $79.72 \pm 15.17$ & 0.7881 \\
\hline ST - T Changes & $12(24 \%)$ & $6(12 \%)$ & 0.1931 \\
\hline AF & ARRHYTHMIAS: no. of patients (\%) & 0.4331 \\
\hline PVC & 5(18\%) & $2(4 \%)$ & 1.0000 \\
\hline SVT & $5(10 \%)$ & $3(16 \%)$ & 0.7124 \\
\hline VT & $5(10 \%)$ & $2(4 \%)$ & 0.4331 \\
\hline INOTROPES/VASOPRESSORS requirement no. of patients (\%) \\
\hline N
\end{tabular}

$\mathrm{N}=$ Norepinephrine, $\mathrm{D}=$ Dobutamine, $\mathrm{A}=$ Adrenaline, $\mathrm{AF}=$ Atrial Fibrillation, $\mathrm{PVC}=$ Premature Ventricular Complex, SVT=Supraventricular Techycardia, VT=Ventricular Techycardia

Statistics of arrhythmic events- With regards to arrhythmias there were no statistically significant differences in either of the groups $(\mathrm{P}>0.05)$. However, incidence of arrhythmias was lower in group B. (Table 4)

Statistics of myocardial ischemic events- The definition of an ST segment event included a ST-segment elevation of $2.0 \mathrm{~mm}$ or a ST-segment depression of $1.0 \mathrm{~mm}$ (duration $\geq 60 \mathrm{sec}$; interval time $\geq 180 \mathrm{sec}$ ). Only ST-segment depressions were detected in either of the groups. No ST-segment elevation was detected in any of the groups.

Though there were less number of cases having ST-depression in Dexmedetomidine group, there was no statistically significant difference between the number of cases in groups A and B (12 and 6 cases, respectively; P>0.05). (Table4) 


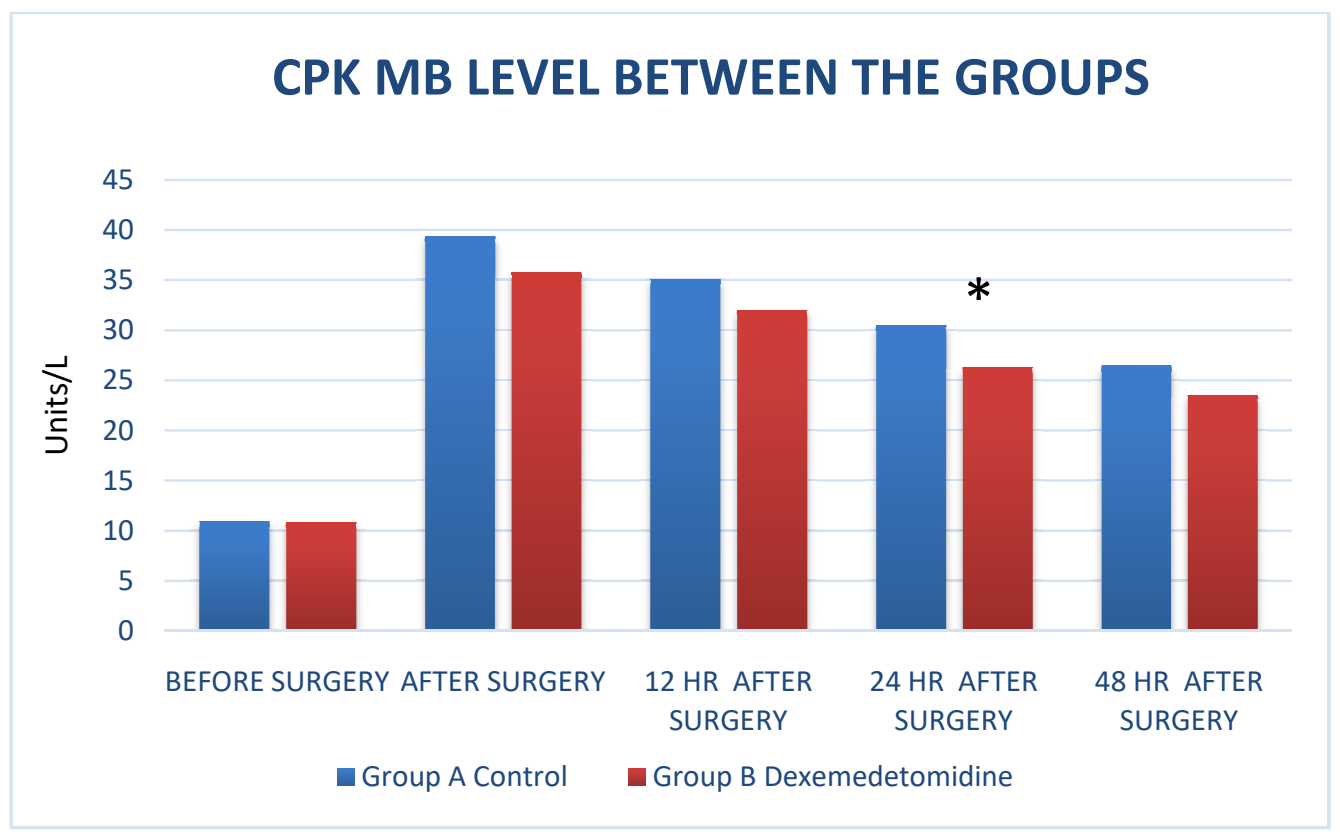

*P VALUE $<0.05$ between the groups

Figure-3: CPK MB level between the groups

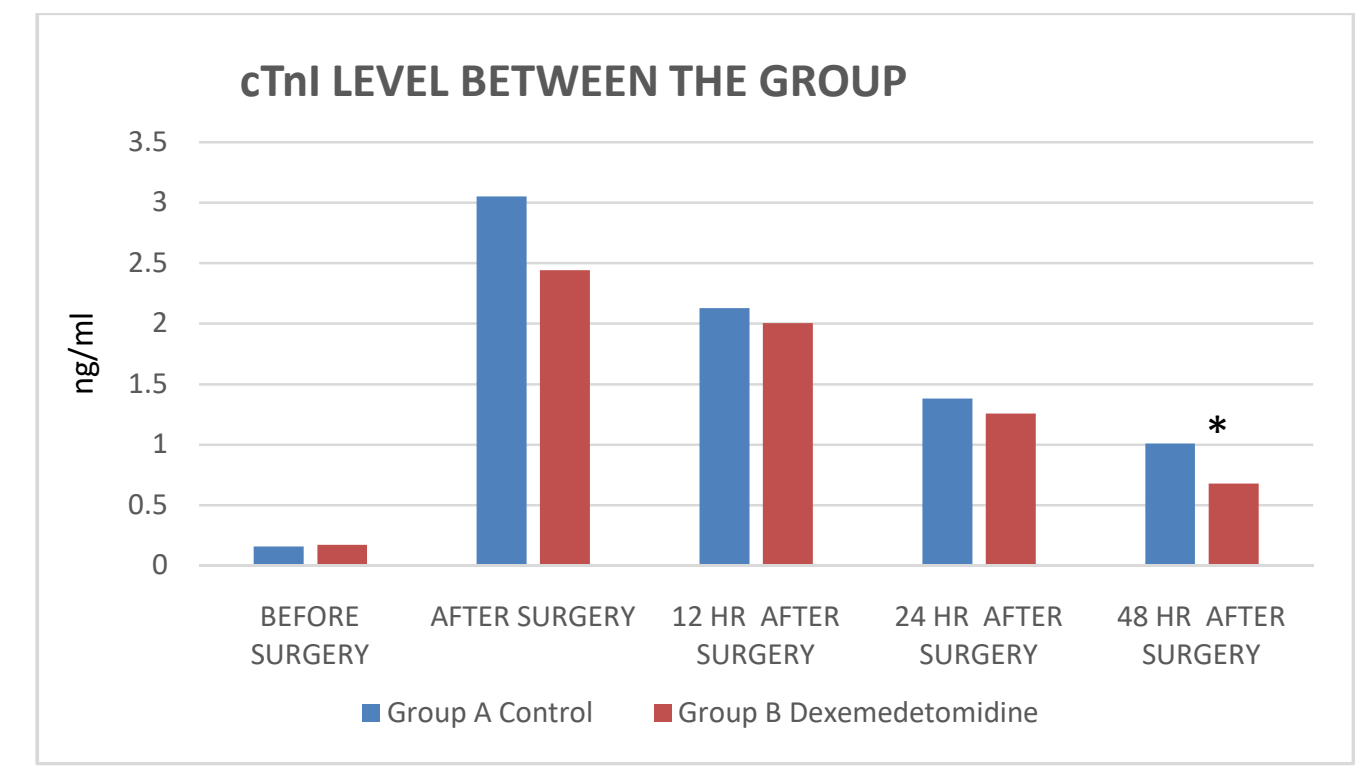

*P VALUE $<0.05$ between the groups

Figure-4: cTnl level between the group

Comparison of Post-operative outcome- There were no statistically significant differences between either of the groups with regards of duration of post-operative ventilation, length of stay in ICU, inotropes requirement, morbidity and mortality $(\mathrm{P}>0.05)$. (Table 4)

\section{Discussion}

This study demonstrated that OPCAB surgery induces release of cardiac biochemical markers cTnI and CK-MB, however in patients received Dexmedetomidine, decreased level of cardiac biochemical markers were observed. CTnI and CK-MB are unique biomarkers for myocardial injuries. Within $20 \mathrm{~h}$ subsequent to surgery, the increase in cTnI level is an independent factor that is predictive of the post-surgical hospital mortality of a patient [9]. Furthermore, the cTnI 
level may be used to predict the prognosis of patients and the occurrence of two-year post-surgical cardiac ischemic events [10-12]. CK-MB is not a specific myocardial injury indicator, but it exhibits an identical function to cTnI when its concentration is $>20$ IU $[13,14,15]$. Therefore, in the present study, cTnI and CK-MB were utilized as indicators in order to observe the impact of dexmedetomidine on myocardial injuries.

Synopsys of the results- In this prospective, randomized, placebo control study, we observed reversible increases in the serum CK-MB and cTnI concentrations after OPCAB in both the groups. It suggests that CABG surgery without CPB also induces the myocardial damage which was reduced by administration of a $0.5 \mu \mathrm{g} / \mathrm{kg} / 10$ min loading dose followed by $0.5 \mu \mathrm{g} / \mathrm{kg} / \mathrm{h}$ infusion dose of dexmedetomidine. However, higher CI values were seen earlier in Group B than in Group A. Furthermore, CVP, MPAP and PCWP tended to be lower in Group B than in Group A.

We observed that heart rate was higher in control group when compared with dexmedetomidine group after starting dexmedetomidine loading followed by continuous infusion. When heart rate at different time points were compared with baseline values in the particular group, lower heart rate values were observed after starting of dexmedetomidine infusion. None of the patients in any group required pacemaker or pharmacological interventions to correct the heart rate.

Systolic Arterial Blood Pressure (SAP) and Diastolic Arterial Blood Pressure (DAP) were significantly higher in the control group when compared with dexmedetomidine group. CVP, MPAP and PCWP were significantly at lower side in Dexmedetomidine group as compared to control group. Although Cardiac Output and Cardiac index were decreased after starting Dexmedetomidine infusion, we observe higher CO \& CI values than the control group.

Lower incidences of arrhythmias \& ST-T changes were recorded in Dexmedetomidine group. All the arrhythmias observed in both groups were transient only and they were subsided spontaneously or with correction of electrolytes imbalance and did not require any major intervention.

Justification of the study- As we observed CABG surgery without CPB also induces the myocardial damage which can reliably detected by increased plasma concentration of CPK-MB and cTnI post operatively. The extent of these injuries is directly proportional to cardiac biomarker release. The increase in these biomarkers is an indicator of cell death. Myocardial injury seems to be reduced by administration of a $0.5 \mu \mathrm{g} / \mathrm{kg} / 10$ min loading dose and a $0.5 \mu \mathrm{g} / \mathrm{kg} / \mathrm{h}$ infusion dose of dexmedetomidine in our study.

The techniques used in OPCAB surgery may lead to some myocardial cell injury [16]. Myocardial cell injury predominantly occurs due to the relative reduction in the myocardial oxygen supply during vascular anastomosis grafting, a lack of perfusion, leading to myocardial ischemia, or an ischemia reperfusion injury, all of which reduce the heart rate and myocardial contractile force during vascular anastomosis grafting.

In the present study, a dynamic electrocardiogram was obtained $72 \mathrm{~h}$ post-surgically, and 12 and six patients were observed to have myocardial ischemia (ST-segment depression of $1.0 \mathrm{~mm}$ duration, $\geq 60 \mathrm{sec}$; interval time $\geq 180 \mathrm{sec}$ ) in control and Dexmedetomidine groups, respectively. This result indicated that in the experimental conditions of this study, dexmedetomidine was able to reduce the incidence of post-surgical myocardial ischemic events, which may be a primary mechanism in reducing post-surgical myocardial cell injury.

The potential reduction in myocardial ischemia due to dexmedetomidine may be associated with a variety of factors. For example, the method of administration in this study was altered, compared with standard practice. The recommended method of administration is a load of $1 \mu \mathrm{g} / \mathrm{kg}$ and an infusion time of $>10 \mathrm{~min}$, followed by an additional $0.2-0.7 \mu \mathrm{g} / \mathrm{kg} / \mathrm{h}$ for maintenance [17]. However, high blood pressure and bradycardia occur at this load; thus, many clinicians suggest avoiding the recommended load, in order to reduce the adverse effects of higher dose of dexmedetomidine that may induce alteration in hemodynamics of patients with severe cardiovascular complications [18]. The $\alpha 2$-receptor agonist, dexmedetomidine, may constrict the coronary arteries and reduce coronary blood flow [19, 20]. Blood flow is further reduced in patients with atherosclerosis, which may result in myocardial ischemia. Patients who undergo OPCAB surgery often have complications, such as atherosclerosis, hyperlipidemia, hypertension and diabetes mellitus. The 
synergistic effect of anesthesia-inducing drugs and dexmedetomidine may adversely influence ischemic myocardium. During the surgery, cardiac function considerably improves following the first vascular grafting (primarily for the anterior descending branches), as evidenced by the enhanced myocardial contractile force and a rise in blood pressure. Therefore, in this study, the patients were administered dexmedetomidine following the first vascular grafting to avoid the hemodynamic fluctuation on myocardial ischemia.

Dexmedetomidine may decrease the heart rate and blood pressure and thus reducing myocardial oxygen consumption. In addition to the mechanical cell injuries that occur as a result of the surgery itself [16], heart rate, blood pressure and vascular anastomosis time are the predominant factors that lead to myocardial cell injury during OPCAB. Lake of perfusion during vascular anastomosis results in certain hypoxic regions in the myocardium leads to ischemia or ischemia-reperfusion injury. When this occurs, reducing the heart rate and myocardial contractile force using $\beta$-receptor blockers may reduce myocardial oxygen consumption, which is critical in reducing ischemic injury [2, 21].

Dexmedetomidine causes sympathetic blockade, as it affects the $\alpha 2$-receptors in the central nervous system, restrains the release of the central sympathetic neurotransmitter (predominantly norepinephrine), induces the peripheral sympatholysis and simultaneously excites the vagus nerve to reduce the heart rate [22]. In the present study, the heart rate and blood pressure of the patients in Dexmedetomidine group were significantly lower than those in Control group. When the heart rate decreases, the post-surgical cardiac oxygen demand also decreases, thus facilitating the maintenance of the myocardial oxygen supply and demand balance. Therefore, these effects not only protect the ischemic myocardium prior to grafting, but also reduce the post-surgical incidence of myocardial injury.

Table-5: Comparison with literature and clinical consequences of our findings

\begin{tabular}{|c|c|c|c|c|c|c|}
\hline Study Name & $\mathbf{n}$ & $\begin{array}{l}\text { With } \\
\text { CPB or } \\
\text { without } \\
\text { CPB }\end{array}$ & $\begin{array}{l}\text { Dexmedetomidne dose \& } \\
\text { method of administration }\end{array}$ & $\begin{array}{c}\text { Result } \\
\text { Myocardial } \\
\text { protection } \\
\text { yes/ no }\end{array}$ & $\begin{array}{l}\text { Myocardial } \\
\text { Protection in } \\
\text { form of }\end{array}$ & $\begin{array}{l}\text { Comparing with } \\
\text { our study }\end{array}$ \\
\hline $\begin{array}{c}\text { Jalonen,et } \\
\text { al(1997) (23) }\end{array}$ & 40 & $\begin{array}{l}\text { With } \\
\text { CPB }\end{array}$ & $\begin{array}{l}1.5 \mu \mathrm{g} / \mathrm{kg} / 30 \mathrm{~min} \text { as the } \\
\text { loading and } 0.42 \mu \mathrm{g} / \mathrm{kg} / \mathrm{h} \text { as } \\
\text { the maintenance }\end{array}$ & No & $\begin{array}{c}\text { ECG based } \\
\text { ischemic events }\end{array}$ & $\begin{array}{l}\text { We used a lower } \\
\text { loading dose of } \\
\text { dexmedetomidine }\end{array}$ \\
\hline $\begin{array}{l}\text { ZeynepTosun,et } \\
\operatorname{al}(2013) \\
\text { (7) }\end{array}$ & 40 & $\begin{array}{l}\text { With } \\
\text { CPB }\end{array}$ & $\begin{array}{l}\text { loading dose of } 0.5 \\
\mu \mathrm{g} / \mathrm{kg} / 10 \mathrm{~min} \text {, followed by a } \\
\text { continuous infusion of } 0.5 \\
\mu \mathrm{g} / \mathrm{kg} / \mathrm{h} \text { (low dose) until the } \\
\text { end of surgery }\end{array}$ & No & $\begin{array}{c}\text { Cardiac } \\
\text { Biomarkers }\end{array}$ & $\begin{array}{l}\text { Same dosing } \\
\text { method but without } \\
\text { CPB }\end{array}$ \\
\hline $\begin{array}{l}\text { Jianjunren and } \\
\text { colleagues } \\
(2013)(24)\end{array}$ & 162 & $\begin{array}{l}\text { Off- } \\
\text { Pump }\end{array}$ & $\begin{array}{c}0.2-0.5 \mu \mathrm{g} / \mathrm{kg} / \mathrm{h} \text { (low dose), } \\
\text { without loading dose \& } \\
\text { infusion was continued for } 12 \\
\text { hours post-surgery }\end{array}$ & Yes & $\begin{array}{c}\text { Cardiac } \\
\text { Biomarkers + } \\
\text { ECG based } \\
\text { ischemic events }\end{array}$ & $\begin{array}{l}\text { Loading dose was } \\
\text { given }\end{array}$ \\
\hline $\begin{array}{l}\text { Shoulin Chen } \\
\text { and colleagues } \\
(2015)(25)\end{array}$ & 64 & $\begin{array}{l}\text { With } \\
\text { CPB }\end{array}$ & $\begin{array}{l}\text { loading dose of } 0.5 \mu \mathrm{g} / \mathrm{kg} \text { for } \\
10 \text { min, followed by a } \\
\text { continuous infusion of } 0.5 \\
\mu \mathrm{g} / \mathrm{kg} / \mathrm{hr} \text { until the completion } \\
\text { of CABG }\end{array}$ & Yes & $\begin{array}{c}\text { systemic } \\
\text { inflammatory } \\
\text { markers }+ \\
\text { Cardiac } \\
\text { Biomarkers }\end{array}$ & $\begin{array}{c}\text { systemic } \\
\text { inflammatory } \\
\text { markers were not } \\
\text { studied }\end{array}$ \\
\hline \multirow[t]{2}{*}{$\begin{array}{l}\text { Xiaohui Chi and } \\
\text { colleagues } \\
(2016)(9)\end{array}$} & \multirow[t]{2}{*}{100} & \multirow[t]{2}{*}{$\begin{array}{l}\text { Off- } \\
\text { Pump }\end{array}$} & $\begin{array}{l}\text { high-dose group (loading } \\
\text { dose, } 1 \mu \mathrm{g} / \mathrm{kg} ; \text { maintenance } \\
\text { dose, } 0.6 \mu \mathrm{g} / \mathrm{kg} / \mathrm{h}) ;\end{array}$ & Yes & \multirow[t]{2}{*}{$\begin{array}{c}\text { Cardiac } \\
\text { Biomarkers }\end{array}$} & \multirow{2}{*}{$\begin{array}{c}\text { we used only low } \\
\text { dose of } \\
\text { dexmedetomidine } \\
\text { and we observed a } \\
\text { decline in cardiac } \\
\text { enzyme levels }\end{array}$} \\
\hline & & & $\begin{array}{c}\text { low-dose group (loading } \\
\text { dose }, 0.6 \mu \mathrm{g} / \mathrm{kg} ; \text { maintenance } \\
\text { dose }, 0.3 \mu \mathrm{g} / \mathrm{kg} / \mathrm{h} \text { ) }\end{array}$ & No & & \\
\hline
\end{tabular}

In a study where dexmedetomidine was applied to volunteers, an excessive infusion dosage or a very rapid infusion rate was observed to lead to a biphasic blood pressure response or a transient increase in blood pressure (particularly during 
the load period). When the plasma level of dexmedetomidine decreased, the blood pressure dropped and remained at lower levels [22]. In our study we found Dexmedetomidine bolus induced hypertension in $8 \%$ of patients in dexmedetomidine group, however they were present for a brief period only and resolved without any intervention. Thus, overall cardiac afterload, myocardial oxygen consumption and myocardial ischemia injury all decreased during the surgery.

Comparison with literature and clinical consequences of our findings: (Table 5) In the study by Jalonen,et al, [23] all patients underwent CABG surgery with CPB with higher loading dose of dexmedetomidine and the observation method and time of ischemic events were different. In the current study, the dynamic electrocardiogram was monitored from the end of the surgery, until 72 hours post-surgery, and biomarkers were monitored. These differences may have led to different observation results.

ZeynepTosun et al [7] in 2013, studied cardioprotective effect of Dexmedetomidine during coronary artery bypass graft surgery with cardiopulmonary bypass (CPB). They concluded that myocardial damage was not reduced by administration of $0.5 \mu \mathrm{g} / \mathrm{kg}$ loading dose and $0.5 \mu \mathrm{g} / \mathrm{kg} / \mathrm{h}$ infusion of dexmedetomidine. However MPAP tended to be lower in the dexmedetomidine group. We observed a decline in cardiac enzyme levels at 48 hours after surgery suggesting myocardial protection.

Jianjunren and colleagues [24], in 2013, studied the protective effect of dexmedetomidine in off-pump coronary artery bypass grafting surgery and they observed reduction of post-surgical myocardial ischemia and reduction in incidence of arrhythmia. Our findings are consistent with this study.

Shoulin Chen and colleagues [25], in 2015, had similar findings as compare to our study. They had also studied inflammatory cytokines like tumor necrosis factor-alpha (TNFalpha), interleukin (IL)-6, IL-8 and IL-10. They showed Dexmedetomidine inhibited the increase in cTnI and CK-MB, attenuated the production of pro-inflammatory cytokines TNF-alpha, IL-6 and IL-8, and promoted anti-inflammatory cytokine IL-10 production. These findings demonstrate that Dexmedetomidine regulates anti-inflammatory as well as myocardial protection potential in CABG with CPB.

Xiaohui Chi and colleagues [9], in 2016, Observed that myocardial damage was reduced by the administration of a 1$\mu \mathrm{g} / \mathrm{kg}$ loading dose and a $0.6-\mu \mathrm{g} / \mathrm{kg} / \mathrm{h}$ infusion of dexmedetomidine (high-dose group) but not with the low dose group. In our study we observed a decline in cardiac enzyme levels at 48 hours after surgery without notably any major fluctuation in hemodynamics with dexemedetomidine $05 \mu \mathrm{g} / \mathrm{kg}$ loading followed by $0.5 \mu \mathrm{g} / \mathrm{kg} / \mathrm{hr}$ infusion.

\section{Conclusions}

Intraoperative administration of low-dose dexmedetomidine, $0.5 \mu \mathrm{g} / \mathrm{kg} / 10 \mathrm{~min}$ of loading followed by $0.5 \mu \mathrm{g} / \mathrm{kg} / \mathrm{h}$ of infusion dose, reduce myocardial damage during off-pump coronary artery bypass grafting surgery as indicated by significantly decreased level of cardiac biochemical markers, CKMB and cTnI post-operatively and also maintains hemodynamic stability intra operatively as well as post operatively. The incidences of arrhythmias and postsurgical myocardial ischemia decreased with Dexmedetomidine.

Funding: Nil, Conflict of interest: None. Permission of IRB: Yes

\section{References}

1. Ascione R, Lloyd CT, Underwood MJ, Lotto AA, Pitsis AA and Angelini GD: Inflammatory response after coronary revascularization with or without cardiopulmonary bypass. Ann ThoracSurg. 2000; 69 (4): 1198-1204 DOI: 10.1016/S0003-4975(00)01152-8.

2. Ketenci B, Enc Y, Ozay B, et al: Myocardial injury during off-pump surgery. The effect of intraoperative risk factors. Saudi Med J. 2008; 29: 203-208.

3. Karu I, Tähepõld P, Sulling TA, Alver M, Zilmer M, Starkopf J. Off-pump coronary surgery causes immediate release of myocardial damage markers. Asian Cardiovasc Thorac Ann. 2009; 17(5):494-9. doi: 10.1177/0218492309348637. 
4. Naseri E, Sevinc M, Erk MK: Comparison of offpump and conventional coronary endarterectomy. Heart Surg Forum. 2003; 6(4):216-9.

5. Wei M, Jian K, Guo Z, et al: Effects of half-dose aprotinin in off-pump coronary artery bypass grafting. World J Surg. 2006 Jun; 30(6):1108-14.

6. Woo YJ, Grand TJ, Zentko S, et al: Creatine phosphate administration preserves myocardial function in a model of off-pump coronary revascularization. $\mathbf{J}$ Cardiovasc Surg (Torino). 2005; Jun 46(3):297-305.

7. Tosun Z, Baktir M, Kahraman HC, et al: Does dexmedetomidine provide cardioprotection in coronary artery bypass grafting with cardiopulmonary bypass? A pilot study. J Cardiothorac Vasc Anesth. 2013 Aug; 27(4):710-5. doi: 10.1053/j.jvca.2012.12.013.

8. Sulaiman S, Karthekeyan RB, Vakamudi M, et al: The effects of dexmedetomidine on attenuation of stress response to endotracheal intubation in patients undergoing elective off-pump coronary artery bypass grafting. Ann Card Anaesth. 2012; 15 (1):39-43.

9. Xiaohui Chi, Mingfeng Liao, Xin Chen, Yilin Zhao, Liu Yang, AilinLuo and Hui Yang, "Dexmedetomidine Attenuates Myocardial Injury in Off-Pump Coronary Artery Bypass Graft Surgery," Journal of Cardio thoracic and Vascular Anesthesia. 2016; 30(1):44-50. DOI: 10.1053/j.jvca.2015.06.026.

10. Fellahi JL, Gué X, Richomme X, Monier E, Guillou L and Riou B: Short-and long-term prognostic value of postoperative cardiac troponin I concentration in patients undergoing coronary artery bypass grafting. Anesthesiology. 2003; Aug 99(2):270-4.

11. Lasocki S, Provenchère $S$, Bénessiano $J$, et al: Cardiac troponin $\mathrm{I}$ is an independent predictor of in-hospital death after adult cardiac surgery. Anesthesiology. 2002; Aug 97(2):405-11.

12. Van Geene Y, van Swieten HA and Noyez L: Cardiac troponin I levels after cardiac surgery as predictor for in-hospital mortality. Interact CardioVasc Thorac Surg. 2010; 10 (3): 413-416. DOI: https://doi.org/10.1510/icvts.2009.216408

13. Paparella D, Cappabianca G, Malvindi P, et al: Myocardial injury after off-pump coronary artery bypass grafting operation. Eur $\mathrm{J}$ CardiothoracSurg. 2007; 32: 481-487.

14. Tempe DK, Dutta D, Garg M, Minhas H, Tomar A and Virmani S: Myocardial protection with isoflurane during off-pump coronary artery bypass grafting: a randomized trial. J CardiothoracVasc Anesth. 2011; 25: 59-65.

15. Vanden Eynden F, Cartier R, Marcheix B, Demers P and Bouchard D: Prognosis of perioperative myocardial infarction after off-pump coronary artery bypass surgery. J Cardiovasc Surg (Torino). 2009; Aug 50(4):535-43.

16. Selvanayagam JB, Petersen SE, Francis JM, et al: Effects of off-pump versus on-pump coronary surgery on reversible and irreversible myocardial injury: a randomized trial using cardiovascular magnetic resonance imaging and biochemical markers. Circulation. 2004; 109: 345-350. doi.org/10.1161/01.

17. Gerlach AT and Dasta JF: Dexmedetomidine: an updated review. Ann Pharmacother. 2007; Feb; 41(2):245-52.

18. Dasta JF, Kane-Gill SL and Durtschi AJ: Comparing dexmedetomidine prescribing patterns and safety in the naturalistic setting versus published data. Ann Pharmacother. 2004; Jul-Aug 38(7-8):1130-5.

19. Willigers HM, Prinzen FW and Roekaerts PM: Comparison of the effects of dexmedetomidine and esmolol on myocardial oxygen consumption in dogs. Eur J Anaesthesiol. 2004; Dec 21(12):957-66.

20. Snapir A, Posti J, Kentala E, et al: Effects of low and high plasma concentrations of dexmedetomidine on myocardial perfusion and cardiac function in healthy male subjects. Anesthesiology. 2006; 105(5):902-10. DOI: $10.1097 / 00000542-200611000-00010$

21. Kurita A and Shintani H: Risk factors for myocardial injury during off-pump coronary artery bypass grafting. Heart Surg Forum. 2005; 8(6):E401-5.

22. Penttilä J, Helminen A, Anttila M, Hinkka S and Scheinin H: Cardiovascular and parasympathetic effects of dexmedetomidine in healthy subjects Can J Physiol Pharmacol. 2004; May 82(5):359-62. 


\section{Original Research Article}

23. Jalonen J, Hynynen M, Kuitunen A, et al: Dexmedetomidine as an anesthetic adjunct in coronary artery bypass grafting. Anesthesiology. 1997; Feb 86(2):331-45.

24. Ren J, Zhang H, Huang L, Liu Y, Liu F, Dong Z. Protective effect of dexmedetomidine in coronary artery bypass grafting surgery. Experimental and Therapeutic
Medicine

2013;6(2):497-502. doi:10.3892/etm.2013.1183.

25. Chen S, Hua F, Lu J, et al. Effect of dexmedetomidine on myocardial ischemia-reperfusion injury. International Journal of Clinical and Experimental Medicine. 2015; 8(11):21166-21172.

\section{How to cite this article?}

Sarvaia A., Pujara J., Sarvaiya V., Pandya H., Trivedi V., Ninama S.K., Acharya H. Role of dexmedetomidine in myocardial protection during beating coronary artery bypass grafting.. Int J Med Res Rev 2017;5(02):176-187. doi:10.17511/ijmrr. 2017.i02.13. 